\title{
Management Practices from Questionnaire Surveys in Herds with Very Low Somatic Cell Score Through a National Mastitis Program in France
}

\author{
J. Barnouin, ${ }^{1}$ M. Chassagne, ${ }^{1}$ S. Bazin, ${ }^{2}$ and D. Boichard ${ }^{3}$ \\ ${ }^{1}$ Animal Epidemiology Research Unit, INRA, \\ 63122 Saint Genès Champanelle, France \\ ${ }^{2}$ France Contrôle Laitier, 167 rue du Chevaleret, \\ 75013 Paris, France \\ ${ }^{3}$ Département de Génétique Animale, INRA, \\ 78352 Jouy en Josas Cedex, France
}

\section{ABSTRACT}

French dairy herds $(\mathrm{n}=534)$ were enrolled in the National 'Zero Mastitis Objective' Program to highlight management practices characterizing very low somatic cell score (SCS) herds. The herds studied were stratified into 2 groups. The first group (LOW) included herds within the first 5 percentiles and the second group (MED) herds within the 50 to 55 percentiles of herds on the basis of mean SCS for the 36 mo preceding the program. Potential explanatory variables, collected through questionnaire surveys, were analyzed using multistep logistic regression models. Twenty-six variables were significant factors in the final models, in which 18 were considered as primary factors for very low SCS. The probability for a herd belonging to the LOW group was associated with: (1) regular use of teat spraying; (2) herdsman precise in his techniques; (3) less than 1 person-year used at activities other than dairy herd; (4) teat dipping after mammary infusion at dry off; (5) heifers kept in a calving pen around parturition; (6) cows locked in feed-line lockups after milking; (7) dry cows with prepartum Ca restriction; (8) heifers on a nondamp pasture; (9) cows culled when at least one damaged teat; (10) heifers at pasture not drinking water from a river; and (11) disinfecting teat ends with alcohol before intramammary infusion at dry off. The probability for a herd belonging to the MED group was associated with: (1) milking cows housed in a straw yard; (2) checking heifers for mastitis only beginning at 2-wk prepartum; (3) no mastitis treatment when at least one clot was observed in milk at successive milkings; (4) distance of herdsman's house to cowshed $>300 \mathrm{~m}$; (5) only dirty teats washed before milking; (6) free access of cows from pasture to cowshed during bad weather; and (7) more than 18\% of spring calvings.

Received March 1, 2004.

Accepted August 4, 2004

Corresponding author: J. Barnouin; e-mail: barnouin@clermont. inra.fr.
The variables associated with very low SCS should be applied as part of a thorough mastitis-control program adapted to each herd.

(Key words: somatic cell score, management practice)

Abbreviation key: 36-mo SCS = mean somatic cell score for the 36 mo preceding the beginning of the survey, BMCC = bulk milk somatic cell count, INRA = Institut National de la Recherche Agronomique, LOW = very low SCS herds, MED = medium SCS herds, PRIM = primary final logistic model; $\mathbf{S E C}=$ secondary final logistic model; ZMP = 'Zero Mastitis Objective' Program.

\section{INTRODUCTION}

Mastitis remains the most costly production disease in the dairy cow (Seegers et al., 2003), resulting for more than one century in many experimental trials, epidemiological surveys, meetings, and discussions (Mayo, 1895). Because mastitis is a multifactorial health problem, several strategies are necessary to obtain a better understanding of risk factors involved in the disease and its consequences on milk quality through pathogens, increased SCC, and changes in milk chemical composition (Urech et al., 1999; Coulon et al., 2002). Characterizing management and hygiene practices of quality dairy herds (vs. medium or low quality herds) is a new way to highlight breeding practices associated with a high degree of control of clinical and subclinical udder infections (Erskine et al., 1987; Hutton et al., 1990; Barkema et al., 1998a). As preventive programs based on milking-machine control, dry-cow antibiotic therapy, postmilking teat disinfection, and culling of cows with chronic mastitis have been implemented in numerous countries, the level of subclinical infections has been reduced (Schukken et al., 1989a). Today, most herds have some kind of control program to reduce SCC. Determining the management practices characterizing very low SCC herds does not ensure that such practices are etiologically associated with mastitis 
risk (Barkema et al., 1998a). Moreover, low milk SCC can be linked with farmer's management style (Barkema et al., 1999), as well as with fads and fashionable practices. Such procedures are sometimes performed despite improbable effectiveness because they remain untested (Hogan and Smith, 2001) or they benefit from marketing campaigns. Moreover, mastitis and dairy farming are complex biological and decision systems involving interactions between animals, environment, and farmers (Tarabla and Dodd, 1990), an unfavorable context in which to assess the primary determinants of a risk. Nevertheless, epidemiological studies offer hypotheses that may be elaborated in further clinical or experimental studies (Schukken et al., 1990). But when such experimental trials can be conducted in available herds with sufficient financial support, they are rather difficult to design to give sound results. Mastitis is a multifaceted disease implicating various genetic, immune, environmental, and management conditions having short- and long-term effects of the involved risk factors.

The aim of the present epidemiological work, conducted between February 1999 and August 2001 in French dairy herds selected on a national basis through the 'Zero Mastitis Objective' Program (ZMP), was to highlight from questionnaire surveys management practices and characteristics discriminating between herds with a very low SCC for at least $5 \mathrm{yr}$ (considered as 'going beyond the objective concerning the degree of control of herd SCC') and herds with a medium SCC for at least $5 \mathrm{yr}$ (considered as 'reaching the current objective concerning herd SCC').

\section{MATERIALS AND METHODS}

\section{Herd Selection}

Herd was the epidemiological unit. All the studied herds were included in the national DHIA database. Herds were selected according to the following criteria: at least 20 cows, located in the departments (i.e., counties; $n=48$ ) in which DHIA volunteered to appoint ZMP surveyors, at least $90 \%$ of the cows belonging to the same breed (Holstein, Montbéliarde, or Normande) because breed is a key milk SCS variation factor (Barnouin et al., 1999; Rupp et al., 2000), and no vaccination against mastitis. The study did not involve any payment to the selected farmers, who were considered to be good managers and were advised regularly by competent technicians. Moreover, the farmers declared that they did not change significantly their breeding system during ZMP.

Two samples of herds were constituted according to the herd's previous 36-mo history of somatic cell score (36-mo SCS), because SCS (SCS $=\log _{2}[\mathrm{SCC} / 100.000]$
+3 ) is a criterion not biased by milk discarding. Herd 36-mo SCS was the arithmetic mean of all monthly cow SCS values determined in a herd during the 36 mo preceding the beginning of the study.

Herd samples were stratified on department and breed. The first sample included very low SCS herds (LOW herds) belonging to the first 5 percentiles of herds regarding $36-$ mo SCS. LOW herds had scores $\leq 1.99$ for Montbéliarde, $\leq 2.38$ for Holstein, and $\leq 2.76$ for Normande herds. The second sample included herds belonging to the 50 to 55 th percentiles of herds (MED herds). The MED herds had 36-mo SCS greater than, but close to, the median breed value (i.e., 2.78 for Montbéliarde, 3.22 for Holstein, and 3.32 for Normande herds). In each department, the herds were chosen in the ratio of $3 \mathrm{LOW}$ to 2 MED herds, as another ZMP objective (not concerned by the present article) was to highlight practices linked with clinical mastitis risk in LOW herds. Finally, the number of herds in a department depended on: (1) the number of herds that each local DHIA could survey; (2) the number of available LOW and MED herds; and (3) the percentage of herds per breed in the department. When the numbers of available herds were greater than requested, the herds with the lowest SCS were chosen. Herds $(n=586)$ that matched the criteria were enrolled in the program. Three selected farmers quit the survey before starting. Seven herds were not used because of bovine spongiform encephalopathy. Forty-two farmers quit the program before it ended for various reasons (DHIA resignation, health, lack of time, personal, and unknown reasons) or were discarded for incomplete data. Finally, $326 \mathrm{LOW}$ and $208 \mathrm{MED}$ herds that did not change from one SCS category to another during the survey were compared, representing $91.1 \%$ of the initially enrolled herds.

\section{Data Collection}

The DHIA technicians collected questionnaire data concerning characteristics and management practices of the selected farms by interviewing dairy farmers. Milk samples were collected to determine milk yield, SCC (through Fossomatic cell counters), and other milk-quality parameters. Bacteriological analyses of milk were not available in the study.

The questionnaire was validated by the consensus of an expert working group and pilot interviews of 10 farmers outside ZMP to check its feasibility and comprehensiveness. Questions not easily understood were not included in the questionnaire. In total, the final version of the questionnaire consisted of 1,055 herd characteristics and practices, of which 188 were determined by the technician from preexisting information 
(farm general descriptors, monthly numbers of calvings, milking machine characteristics, milk production, and quality data). The interviewees did not have to answer all questions because some did not apply to their farm (e.g., cubicle characteristics could not be described when the cows were loose-housed in a straw yard). Some information could be quickly collected; for example, 135 characteristics of the feeding system (presence or absence of 45 foodstuffs in the diet of heifers, milking cows, and dry cows) could be collected in 15 to $20 \mathrm{~min}$. Nevertheless, to collect all the questionnaire data, 7 to $8 \mathrm{~h}$ were necessary. Consequently, 2 complementary questionnaires were carried out. The first questionnaire, which concerned basic characteristics of the dairy, cowshed, and milking parlor description, personal characteristics of the herdsman, and milk-quality traits, was administered from October to December 1999. The second questionnaire, which concerned herd housing conditions, feeding system, udder and calving hygiene, and herd health, was administered from October to December 2000. As the farmers declared that their dairy management system would not change during ZMP, we assumed that herd characteristics and practices were fairly stable between the time of the 2 questionnaires. Moreover, we checked that herds did not change from one SCS category to another during the survey period.

Agreement between the responses of the farmers and the observations of DHIA technicians during a milkingparlor visit carried out 13 mo on average after the farmer's interview was evaluated using the Kappa statistic. For hygiene milking practices, recorded through interviews and milking parlor visits, the Kappa coefficient value ranged between 0.66 and 0.79 . It is reasonable to expect that ZMP farmers, as good managers, gave reliable information concerning their management procedures (Schukken et al., 1989b). Nevertheless, as the interviewers were the DHIA technicians of the surveyed farms and had a thorough knowledge of the herd management system, they checked the farmers' answers by requesting confirmation at the end of the interview of any information that seemed erroneous. Finally, questions concerning 15 herd characteristics and practices that involved some inconsistent answers regarding our knowledge of dairy farm management in France were removed from data analyses.

\section{Database}

All data were transmitted to the Institut National de la Recherche Agronomique (INRA) Animal Epidemiology Research Unit and stored in an Access 2000 relational database organized through 34 tables. Herd identification number, breed, SCC data, and other milk traits were extracted from the national DHIA database. Checking procedures for data validity were conducted. They consisted of controlling the missing answers and checking with the herd surveyor if such answers were normal or had to be completed. A set of automatic logical procedures also was implemented through the database to detect erroneous entries (e.g., absence of response concerning free stalls if the cows were housed in a straw yard or yearly number of weeks in which the herd was outdoors $<53 \mathrm{wk})$. Moreover, a double data keyboarding was performed independently by 2 INRA technicians to check keyboarding errors.

\section{Statistical Analyses}

Statistical procedures were conducted using SAS/ STAT 8.1 (SAS Institute Inc., Cary, NC). The dependent variable was the group of herds based on SCS (LOW vs. MED). Herd characteristics and management variables shared by the whole sample were analyzed through 3 main steps.

First, $\chi^{2}$ and Wilcoxon tests were performed through PROC FREQ and PROC NPAR1WAY to screen the univariate relationships between hypothesized explanatory variables and SCS group. Then, the results of the univariate analysis were discussed by the ZMP collaborators (INRA, France Contrôle Laitier, Etablissements Départementaux de l'Elevage, Institut de l'Elevage, Schering Plough Vétérinaire) through a preliminary report (Barnouin et al., 2002). In a second step, significant variables $(P<0.25 ; \mathrm{n}=126)$ through the univariate analysis were selected within 10 categories of management characteristics and practices (Table 1), and 10 multiple regression logistic models were performed by PROC LOGISTIC. In all the logistic models, PROC LOGISTIC modeled the probability that a herd belonged to the LOW group. Moreover, the correlations between selected variables were analyzed (PROC REG and PROC CORR), and if variables were correlated (condition index $>30$ or correlation coefficient $>0.15$ ), only the variable with the best fit was included in the final model. As these selection criteria were more severe than those that were generally used, it was reasonable to expect that within the final models of the present study, the multicolinearity among variables was notably weak. Logistic model building used a backward algorithm that assessed 2-way interaction at each step. Assessment of how the models fitted the data was determined using Hosmer-Lemeshow test (Hosmer and Lemeshow, 1989), residual distribution, and deviance analysis. In a last step, the category models were first combined and those variables $(\mathrm{n}=47)$ selected $(P<$ $0.10)$ from the 10 models were offered to a primary final logistic model (PRIM). Those 18 variables selected ( $P$ 
Table 1. Variables offered to management category models and selected for the final logistic models.

\begin{tabular}{|c|c|c|c|}
\hline Category model & $\begin{array}{l}\text { Variables } \\
\text { offered }\end{array}$ & $\begin{array}{l}\text { Variables } \\
\text { selected }\end{array}$ & Abbreviated wording of selected variables \\
\hline Dry off & 12 & 3 & $\begin{array}{l}\text { Intramammary injection of the } 4 \text { quarters; disinfecting the teat ends } \\
\text { before intramammary infusion; postdipping after intramammary } \\
\text { infusion }\end{array}$ \\
\hline Farm/persons/animals & 8 & 4 & $\begin{array}{l}\text { Farm: cereal cropping; farm: person-years for nondairy activities; } \\
\text { milking parlor modified within } 5 \text { yr; some cows react to their name }\end{array}$ \\
\hline Farmer & 8 & 3 & Personal characteristics: precise; meticulous; tidy \\
\hline Feeding: milking cows & 8 & 2 & $\begin{array}{l}\text { Cows fed concentrate after milking while restrained in feed-line } \\
\text { lockups; dietary sodium bicarbonate; dietary } \mathrm{NaCl}\end{array}$ \\
\hline Housing & 17 & 7 & $\begin{array}{l}\text { Milking cows: housing system; heifers and dry cows in a special area } \\
\text { before and at calving; dry cows in a specific cow shed; dry cows in a } \\
\text { special area; multiparous cows at calving in a special area; distance } \\
\text { farmer's house to cow shed; bad weather: access to cow shed } \\
\text { from pasture }\end{array}$ \\
\hline Mastitis management & 27 & 9 & $\begin{array}{l}\text { Udder scores checked by herd-book; painful udder as mastitis } \\
\text { symptom; checking for milk clots as mastitis symptom; high SCC } \\
\text { cows milked using a special milking unit; high SCC and clinical } \\
\text { mastitis cows milked last; cows culled after } 3 \text { clinical cases } \\
\text { of mastitis occur within } 1 \text { lactation; cows culled having damaged } \\
\text { teats; disinfecting teat ends before intramammary infusion to treat } \\
\text { a clinical mastitis; mastitis treatment when } 1 \text { clot of milk is observed } \\
\text { at successive milkings }\end{array}$ \\
\hline Milking & 18 & 6 & $\begin{array}{l}\text { Herdsman takes time to milk; cleaning only dirty teats; predipping: } \\
\text { foaming product; towels changed between milkings; teat dipping: } \\
\text { frequent teat cup cleaning; teat spraying }\end{array}$ \\
\hline Primiparous cows & 9 & 4 & $\begin{array}{l}\text { Percentage of primiparous cows; udder checking before calving; } \\
\text { drinking water at pasture: origin; housing system: late gestation } \\
\text { and calving }\end{array}$ \\
\hline
\end{tabular}

$<0.05)$ by the PRIM best explained the SCS grouping and were considered to be the primary variables to define a mastitis control program. Then, the variables removed from PRIM were included in a second logistic model (Barkema et al., 1998a) and the 8 variables selected $(P<0.05)$ by the secondary final logistic model (SEC) were considered as secondary explanatory variables for the SCS grouping. As for the 22 significant variables from the univariate analysis that were not selected in the final logistic models, they consisted mainly of calving hygiene and mastitis prevention $(\mathrm{n}=$ $6)$, milking $(\mathrm{n}=4)$, and mastitis management $(\mathrm{n}=3)$ category models (Table 1 ).

\section{RESULTS}

\section{Somatic Cell Score}

Mean milk SCS was 3.13 in the 208 selected MED herds vs. 2.05 in the 326 LOW herds (Table 2). These SCS corresponded to 270,000 and 125,000 cells $/ \mathrm{mL}$ respectively. Moreover, there were 2.7 times more $(P<$
0.001) cows with a monthly SCC greater than 800,000 cells/mL in the MED than in the LOW herds. The minimum SCS (1.17) corresponded to 80,000 cells $/ \mathrm{mL}$ and was measured in a Holstein herd located in the BasRhin (herd size $=45 ; \%$ of primiparous $=31$; milk yield $=$ $8107 \mathrm{~kg}$ ). Moreover, surveyed farmers declared that their present SCC levels had been stable for $7 \mathrm{yr}(5.2$ $\mathrm{yr}$ in the MED herds vs. $8.1 \mathrm{yr}$ in the LOW herds).

\section{Descriptive Results}

Herd size and farm surface area were less $(P<0.01)$ in the LOW herds, whereas milk yield $(P<0.001)$, milk annual quota $(P<0.05)$, and percentages of primiparous $(P<0.05)$ were greater (Table 2$)$.

\section{Univariate Analysis}

Table 3 displays the univariate analysis of the explanatory variables offered to PRIM and SEC logistic models. The most discriminating variables $(P<0.001)$ that characterized LOW herds through univariate anal- 
Table 2. Study population characteristics differentiating very low (LOW) and medium (MED) SCS of dairy herds enrolled in the 'Zero Mastitis Objective' Program.

\begin{tabular}{|c|c|c|c|c|}
\hline Variable & $\begin{array}{l}\text { All herds, } \\
\mathrm{n}=534\end{array}$ & $\begin{array}{l}\text { LOW herds, } \\
\mathrm{n}=326\end{array}$ & $\begin{array}{l}\text { MED herds, } \\
\mathrm{n}=208\end{array}$ & $P$ \\
\hline Milk cellular score & $2.47(0.58)^{1}$ & $2.05(0.26)$ & $3.13(0.21)$ & $* * *$ \\
\hline \multicolumn{5}{|l|}{ Milk SCC \% of monthly results } \\
\hline$<50,000$ cells $/ \mathrm{mL}$ & 44.0 & 54.1 & 28.3 & $* * *$ \\
\hline$<300,000$ cells $/ \mathrm{mL}$ & 12.9 & 8.2 & 20.3 & $* * *$ \\
\hline$<800,000$ cells $/ \mathrm{mL}$ & 4.6 & 2.8 & 7.5 & $* * *$ \\
\hline Duration of time with the present SCC, yr & $7.0(4.5)$ & $8.1(4.4)$ & $5.2(4.1)$ & ** \\
\hline Farm surface area, ha & $82.9(48.4)$ & $76.7(39.2)$ & $92.7(58.8)$ & ** \\
\hline No. of cows & $40(14)$ & $41(15)$ & $46(16)$ & ** \\
\hline Primiparous cows, $\%$ of herd & 29.1 & 29.4 & 28.6 & * \\
\hline Milk annual quota, $10^{3} \mathrm{~L}$ & $273(114)$ & $266(111)$ & $284(119)$ & * \\
\hline Milk yield, kg/cow per yr & $7283(947)$ & $7410(980)$ & $7084(859)$ & * \\
\hline
\end{tabular}

ysis were teat spraying $(23.1 \%$ of LOW vs. $9.1 \%$ of MED herds) and herdsman considering himself precise in his techniques $(82.5 \%$ of LOW vs. $68.5 \%$ of MED herds). The most discriminating variables characterizing MED herds were udder checking for mastitis beginning $<2$ wk before the first calving (21.1\% of MED vs. $10.4 \%$ of LOW herds), no mastitis treatment when only one clot was detected in the milk at successive milkings (72.1\% of MED vs. 57.4\% of LOW herds), and dairy cows housed in a straw yard (62.0\% of MED vs. $37.4 \%$ of LOW herds).

\section{Multivariate Analyses}

In the PRIM (final score $=102.8, P<0.001,18 \mathrm{df}$; Table 4), the goodness-of-fit test indicated that the data fit the model well $(P=0.38)$. The deviance was 555.4 on $515 \mathrm{df}(P=0.10)$, the residual plots affirmed the fit of the data, and the final model classified $81 \%$ of the herds into the correct category. In SEC (Table 5), the final score was $58.0(P<0.001,8 \mathrm{df})$, the goodness-offit test indicated that the data fit the model $(P=0.89)$, the deviance was 1.15 ( $1 \mathrm{df}, P=0.128)$, and the model classified $69 \%$ of the herds correctly.

From the PRIM, 18 variables were primary significant factors for SCS level under French conditions (Table 4), whereas only 8 significant secondary factors were detected for SCS level from the SEC (Table 5). According to the PRIM, the probability for a herd to belong to the LOW group was maximized when: (1) milking cows were not housed in a straw yard; (2) checking udder for mastitis in the heifer began before $2 \mathrm{wk}$ prepartum; (3) regular use of teat spraying was carried out (variables 1 to $3 ; P<0.001$ ); (4) herdsman was precise in his techniques; (5) less than 1 person-year was used at activities other than dairy herd; (6) mastitis treatment was performed when one milk clot was ob- served at successive milkings; (7) teat dipping was performed after mammary infusion at dry-off; (8) heifers were housed in a calving pen around parturition; (9) distance herdsman's house to cowshed was $<300 \mathrm{~m}$; (10) cows were restrained by feed-line lockups after milking ; (11) prepartum Ca restriction was performed (variables 4 to $11 ; P<0.01$ ); (12) heifers were on a nondamp pasture; (13) cows were culled when at least one damaged teat was detected; (14) all the teats were washed before milking; (15) no pasture access was allowed during bad weather; (16) more than $18 \%$ of spring calvings; (17) heifers at pasture did not drink from a river; and (18) teats were disinfected with alcohol before intramammary infusion at dry off (variables 12 to 19; $P<0.05)$.

According to the SEC, the probability for a herd to belong to the LOW group was maximized when: (1) cows were housed in a calving pen at parturition; (2) the herdsman asserted that at least 2 cows reacted to their name; (3) a teat disinfection before intramammary infusion was performed to treat a clinical mastitis (variables 1 to $3 ; P<0.01$ ); (4) udder scores were checked by herd-book organization; (5) dry cows were not housed in a separate cowshed; (6) high SCC and mastitic cows were milked last; (7) painful udder was not considered to be a symptom of mastitis; and (8) milking-cow exercise area was scraped more than once daily (variable 4 to $8 ; P<0.05$ ). Figure 1 displays 4 practice boxes summarizing herd factors associated with a high degree of SCC control: (1) specialized and attentive herdsman (Box 1); (2) hygienic living conditions (Box 2); (3) optimized calving conditions (Box 3); and (4) strict teat and udder hygiene (Box 4).

\section{DISCUSSION}

In the ZMP, we aimed to test many management variables. Consequently, we hypothesized that the pri- 
Table 3. Univariate analysis of the $P<0.05$ variables offered to final logistic regression models to study management and hygiene practices in herds with very low (LOW) and medium (MED) SCS.

\begin{tabular}{|c|c|c|c|}
\hline \multirow[b]{2}{*}{ Domain / Variable } & \multicolumn{2}{|c|}{ Herds with the practice $(\%)$} & \multirow[b]{2}{*}{$P$} \\
\hline & $\begin{array}{l}\text { LOW } \\
(\mathrm{n}=326)\end{array}$ & $\begin{array}{l}\text { MED } \\
(\mathrm{n}=208)\end{array}$ & \\
\hline \multicolumn{4}{|l|}{ Calving } \\
\hline Calving pen cleaned after each calving & 50.6 & 39.9 & * \\
\hline Heifers in a calving pen & 57.7 & 46.1 & $* *$ \\
\hline Cows in a calving pen & 57.4 & 47.4 & * \\
\hline Cows in a special area of the cow shed & 39.6 & 26.0 & $* *$ \\
\hline More than $18 \%$ of calvings at spring (March to May) & 22.1 & 30.3 & $*$ \\
\hline \multicolumn{4}{|l|}{ Dry off / late gestation } \\
\hline Dry cows: cow shed regularly disinfected by a specialist company & 8.3 & 3.8 & $*$ \\
\hline \multicolumn{4}{|l|}{ Heifers: starting udder checking for mastitis before calving } \\
\hline$<2 \mathrm{wk}$ & 10.4 & 21.1 & $* * *$ \\
\hline$>8 \mathrm{wk}$ & 22.7 & 13.5 & $* *$ \\
\hline Lowered $\mathrm{Ca}$ supply in late gestation & 43.9 & 34.1 & $*$ \\
\hline Teat dipping after intramammary infusion & 93.6 & 86.1 & $* *$ \\
\hline $\begin{array}{l}\text { Teat disinfection before intramammary infusion to } \\
\text { treat a clinical mastitis }\end{array}$ & 21.2 & 13.9 & $*$ \\
\hline \multicolumn{4}{|l|}{ Farm / cows } \\
\hline Herdsman asserting that at least two cows react to their name & 34.0 & 21.1 & ** \\
\hline Dairy cows: loose-housed in a straw yard & 37.4 & 62.0 & $* * *$ \\
\hline Distance farmer's house-cow shed > $300 \mathrm{~m}$ & 20.9 & 29.8 & * \\
\hline Exercise area of milking cows scraped more than once a day & 15.9 & 9.1 & * \\
\hline Farm activity: cereal cropping & 44.2 & 54.8 & * \\
\hline Free access of the herd to an enclosure from the cow shed & 5.3 & 13.9 & * \\
\hline \multicolumn{4}{|l|}{ Feeding } \\
\hline Milking cows: locked in a feed-line lockups after milking & 49.4 & 35.5 & ** \\
\hline Milking cows: $\mathrm{NaCl}$ supplementation & 73.6 & 64.9 & * \\
\hline \multicolumn{4}{|l|}{ Herdsman } \\
\hline Considers himself meticulous & 72.7 & 62.0 & ** \\
\hline Considers himself precise & 82.5 & 68.5 & $* * *$ \\
\hline Considers himself tidy & 72.4 & 61.5 & $* *$ \\
\hline More than 1 person-year working at activities other than dairy herd & 29.4 & 19.2 & ** \\
\hline Udder scores checked by herd-book organization & 50.0 & 36.1 & $* *$ \\
\hline \multicolumn{4}{|l|}{ Living conditions at pasture } \\
\hline \multicolumn{4}{|l|}{ Drinking water origin at pasture } \\
\hline Heifers: river & 21.8 & 33.2 & ** \\
\hline Heifers: treated well & 50.0 & 61.5 & ** \\
\hline Free access from pasture to cow shed during bad weather & 26.7 & 37.0 & $*$ \\
\hline Heifers on non damp pasture & 28.5 & 18.3 & ** \\
\hline \multicolumn{4}{|l|}{ Milking } \\
\hline Only dirty teats washed before milking & 7.1 & 15.9 & ** \\
\hline Predipping with a foaming product & 12.3 & 18.7 & $*$ \\
\hline Teat dipping cups cleaned after each milking & 90.5 & 83.5 & $*$ \\
\hline Teat spraying & 23.0 & 9.1 & $* * *$ \\
\hline \multicolumn{4}{|l|}{ Udder health: prevention / detection / treatment } \\
\hline \multicolumn{4}{|l|}{ Culling cows having at least: } \\
\hline 1 damaged teat & 54.3 & 44.7 & * \\
\hline 3 mastitis cases & 51.2 & 41.8 & * \\
\hline High SCC and clinical mastitis cows milked last & 37.7 & 28.4 & * \\
\hline High SCC cows milked using a special milking unit & 9.2 & 18.7 & ** \\
\hline Mastitis detection by checking foremilk for clots & 66.3 & 78.8 & $* *$ \\
\hline Mastitis suspected when painful udder at milking & 39.0 & 48.1 & * \\
\hline No mastitis treatment when 1 clot observed in milk & & & \\
\hline at successive milkings & 57.4 & 72.1 & $* * *$ \\
\hline Disinfecting teat ends before curative intramammary infusion & 93.9 & 86.5 & ** \\
\hline
\end{tabular}

mary factors playing a role in mastitis epidemiology were identified. We also assumed that the majority of 'true' observable factors explaining mastitis risk could be part of the variables selected by the PRIM, or even by the SEC. Through the study design and the statistical analyses, we tried to reduce the multicolinearity among explanatory variables, a relatively frequent situation within the dairy management system, and to take ad- 
Table 4. Primary final logistic model for milk cellular score in French dairy herds with very low (LOW) and medium (MED) milk SCS herds (variables sorted by decreasing probability for positive and negative odds ratios).

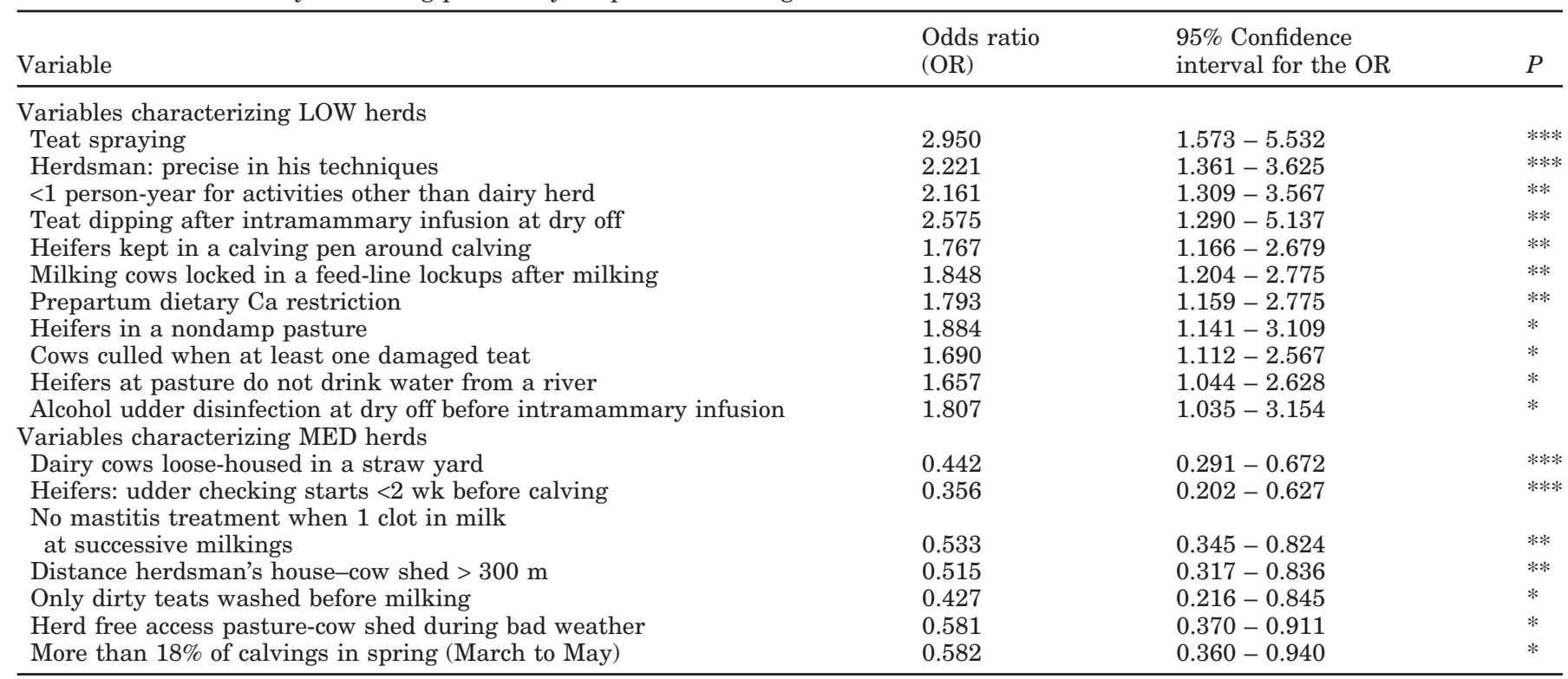

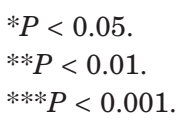

vantage of a large amount of available information. Nevertheless, when large amounts of data are used, finding associations caused by chance increases and experimental studies must be carried out to demonstrate the true relationship between herd management practices and SCS (Barkema et al., 1998a). Most of the time it is very difficult to conduct such experimental trials for feasibility and financial reasons.

The ZMP is the first epidemiological work on bovine mastitis conducted on a national basis using SCS to compare stratified groups of herds with very low and medium somatic cell levels by using multivariate procedures on a large set of characteristics. Somatic cell score is considered to be a better indicator of subclinical mastitis than the more imperfect bulk milk somatic cell count (BMCC; Sargeant et al., 2001). Bulk milk somatic cell count usually is poorly correlated with subclinical infection status (Noordhuizen et al., 1987). Eliminating milk practices that interfere with BMCC could explain unexpected results concerning the relationship between farm hygiene practices and BMCC (Agabriel et al., 1997). Reviewing common factors highlighted in

Table 5. Secondary final logistic model for milk cellular score in French dairy herds with very low (LOW) and medium (MED) milk SCS herds (variables sorted by decreasing probability for positive and negative odds ratios).

\begin{tabular}{|c|c|c|c|}
\hline Variable & $\begin{array}{l}\text { Odds ratio } \\
(\mathrm{OR})\end{array}$ & $\begin{array}{l}95 \% \text { Confidence } \\
\text { interval for the OR }\end{array}$ & $P$ \\
\hline \multicolumn{4}{|l|}{ Variables characterizing LOW herds } \\
\hline Cows kept in a calving pen around calving & 1.905 & $1.275-2.845$ & $0.002^{* *}$ \\
\hline $\begin{array}{l}\text { Herdsman asserting that at least } 2 \text { cows react to } \\
\text { their names }\end{array}$ & 1.887 & $1.230-2.893$ & $0.004^{* *}$ \\
\hline $\begin{array}{l}\text { Teat disinfection before intramammary infusion to } \\
\text { treat a clinical mastitis }\end{array}$ & 2.423 & $1.288-4.556$ & $0.006^{* *}$ \\
\hline Udder and body scores checked by herd-book & 1.643 & $1.127-2.396$ & $0.010^{*}$ \\
\hline High milk SCC and clinical mastitis cows milked last & 1.640 & $1.099-2.448$ & $0.015^{*}$ \\
\hline Exercise area of milking cows scraped $>1$ time/d & 2.037 & $1.133-3.664$ & $0.022 *$ \\
\hline \multicolumn{4}{|l|}{ Variables characterizing MED herds } \\
\hline Dry cows: not housed in cow shed of milking cows & 0.549 & $0.348-0.868$ & $0.011^{*}$ \\
\hline Mastitis suspected when painful udder at milking & 0.631 & $0.434-0.916$ & $0.015^{*}$ \\
\hline
\end{tabular}

$* P<0.05$.

$* * P<0.01$. 


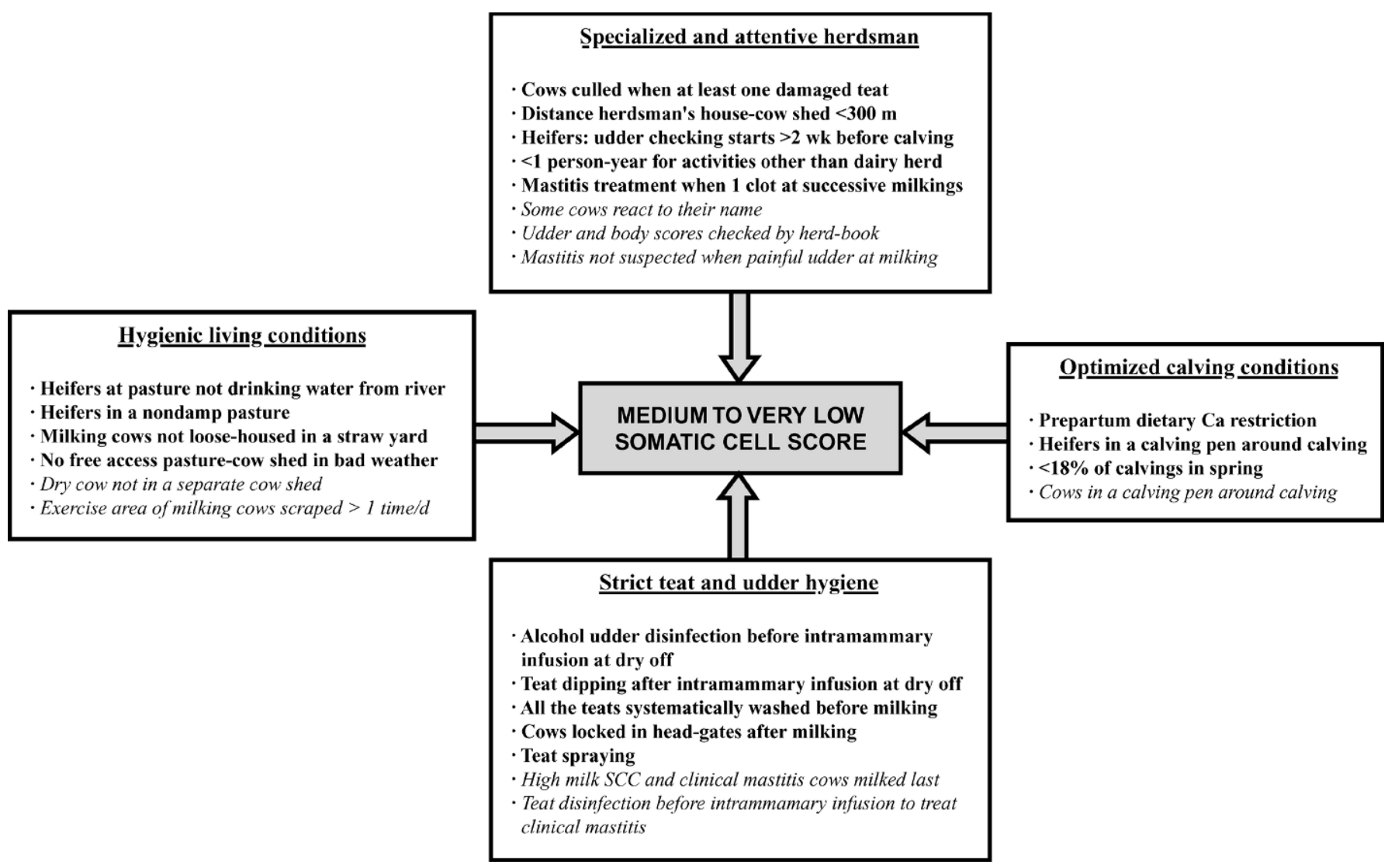

Figure 1. Variables characterizing dairy herds with very low SCS in France (significant variables in the final logistic models: items in bold = primary model; items in italics = secondary model).

studies comparing groups of herds on the basis of BMCC with those displayed in the final PRIM and SEC logistic models can be informative. But, such a comparison is difficult because BMCC categories, collected variables, and statistical procedures (univariate or multivariate models studying confounding factors by several procedures) differed among surveys.

As in the present work, the univariate study of Hutton et al. (1990) demonstrated that cow milking order and teat disinfection before antibiotic infusion characterized low SCC herds. Cows having a dry bedding, a characteristic which was highlighted as a protection factor by Hutton et al. (1991), would correspond in ZMP to 'cows not housed in a straw yard', a characteristic inducing a smaller risk of damp bedding. In Erskine et al. (1987), the risk factors were different, but low SCC herds $(<150,000$ cells $/ \mathrm{mL})$ were compared with very high SCC herds $(>700,000$ cells $/ \mathrm{mL})$, implicating different risk attitudes compared with MED herds. For Barkema et al. (1998a), the variables which discriminated low and medium BMCC differed from those discriminating LOW and MED herds, except regular mastitis checking before calving and cows locked up at the feed- line, 2 practices tending to be used more often in low BMCC herds than medium herds. According to Barkema et al. (1998b), cows were more frequently culled for teat lesions in low BMCC herds. As in the ZMP study, Barkema et al. (1999) found that farmers having low BMCC herds worked more precisely and were more familiar with each cow (a concept close to the 'cows react to their name' variable in our study). Using study designs other than comparisons between stratified groups of herds, management practices decreasing milk SCC have been extensively studied. Nevertheless, some ZMP significant factors were not investigated in any previous work: prepartum Ca restriction in the diet, distance from the farmer's house to the cowshed, mastitis treatment when one milk clot was observed at successive milkings, painful udder not considered as a symptom of mastitis, heifers in a nondamp pasture, and no pasture free access during bad weather.

From the first box of Figure 1, the LOW herdsman had the following characteristics: (1) specialized in dairy farming; (2) lived near the cowshed; (3) considered to be precise in his management techniques (e.g., meticulous and tidy); (4) integrated animal welfare in his 
management ('cows reacting to their names'); and (5) had a positive udder checking attitude (in the heifer, at milking, and via herd-book). Such an attitude involved culling of cows with damaged teats to reduce mastitis recurrence (Bendixen et al., 1988) and mastitis treatments implemented just after observation of clinical signs. A frequent udder checking for mastitis before calving characterized low BMCC herds (Barkema et al., 1998b). The influence of dairy producers' personal characteristics on SCC has been investigated (Tarabla and Dodd, 1990; Barkema et al., 1999). According to these authors, a positive attitude toward animal and milking may influence milk quality by correct application of management practices. Moreover, farmers considered to be clean and accurate know their cows better. Interactivity between the herdsman and his cows would qualify a competent dairy farmer (Albright and Stricklin, 1989). Finally, frequent contacts between herdsmen, technicians, and cows would promote appropriate observations and quick therapeutic decisions at any change in udder or milk appearance ('one clot observed in the milk at successive milkings').

The second box corresponds to characteristics of the cow's life cycle. Regarding housing cows in a straw yard compared with free stalls, our results agree with those of Peeler at al. (2000), who demonstrated that straw yards induce more clinical mastitis cases in low SCC herds. Less mastitis cases are detected in cows housed in free stalls compared with those housed in straw yards (Berry, 1990). Free stalls are linked with fewer SCC (Goodger et al., 1988). Larger SCC and dirtier cows are reported when cows were housed in a straw yard than in free stalls (Fregonesi and Leaver, 2001). Straw bedding promotes rapid growth of various udder pathogens, particularly in humid weather conditions (Zehner et al., 1986). Hutton et al. (1990) reported that DM content of bedding for lactating cows was higher in low SCC herds. Other box 2 variables (heifers in a nondamp pasture and heifers not drinking water from a river, no free access of cows to pasture during bad weather, frequently cleaned exercise area) correspond to living and bedding conditions including a less damp and cleaner environment. Drinking water from sources other than public water increased risk for mastitis (Schukken et al., 1990). Moreover, drinking from a river involves consumption of mud, manure, and water splashes unfavorable to udder hygiene. Bartlett et al. (1992) found lower BMCC in herds having a clean and dry cow exercise area and less risk for mastitis is associated with twice-daily scraping of cow lots (Peeler et al., 2000). Moreover, the fact that nonlactating cows are often housed in poor facilities (Khaitsa et al., 2000) may be associated with greater risks for mastitis in herds in which dry cows and replacement heifers are housed in a separate facilities from lactating cows.

The third box includes variables related to calving conditions. Prepartum dietary Ca restriction, a protective factor against milk fever (Barnouin, 1990), prevents increased lying time after calving and loss of muscle tone in the teat sphincter (Goff, 2003), and subsequent less risk for mastitis. In addition, statistical associations were detected between milk fever and mastitis occurrence (Faye et al., 1986; Schukken, 1990). Menzies and Mackie (2001) indicated that preventive actions minimizing downer cow syndrome would reduce toxic mastitis occurrence. Moreover, longer standing than lying periods were observed in healthy vs. mastitic cows (Vavak, 1990). Calving in a calving pen enables better hygiene at parturition. This practice is an important protective factor against environmental mastitis, and calving pen cleanliness is better in low vs. high BMCC herds (Barkema et al., 1998a). In agreement with this result, the univariate analysis showed that more $(P<0.05)$ LOW herds $(51 \%)$ than MED herds (40\%) cleaned the calving pen after each calving. Because calving is often more stressful for heifers than for cows, use of a calving pen could decrease stress and subsequent attenuated phagocytosis (Barnouin and Chassagne, 2001). Spring calvings (March to May) were associated with a dry off period between January and March, which is less favorable for bedding hygiene. Moreover, spring is the most rainy season in France and is associated with increased mastitis risk (Barnouin et al., 1986).

The early postpartum period is a critical time for mastitis susceptibility (Peeler et al., 2000) via the impairment of the immune system (Burvenich et al., 2003), especially altering the functional capacity of peripheral blood leukocytes (Nonnecke et al., 2003). The greater proportion of polymorphonuclear leukocytes in the milk of spring-calved cows with moderate and high SCC (Kelly et al., 2000) could indicate more frequent mammary infections during spring because of poorer environmental and nutrition conditions during the winter precalving period.

Box 4 highlights the importance of strict udder hygiene for a total control of mastitis risk. The protective effect of teat disinfection before intramammary treatments (preventive/curative) was emphasized by Hutton et al. (1990). Such a practice characterized the low SCC herds in their study. Moreover, as herdsmen in LOW herds also dipped teat more frequently after intramammary infusion, their cows should be well protected against new IMI. Washing only the teats before milking was associated with a lower prevalence of high SCC (Hueston et al., 1990). Nevertheless, no previous study demonstrated the protective effect of a systematic 
washing of the teats even if they appeared clean. To decrease new IMI, other strategies could be developed, as implemented in LOW herds, such as locking up cows at the feed-line after milking, a practice that forces cows to remain standing while the ducts are patent and vulnerable to environmental pathogens (Tyler et al., 1998; Peeler et al., 2000). Consequently, clean and accurate farmers prevented cows from lying down after milking (Barkema et al., 1998b). Cows with clinical mastitis were milked last 3.5 times more frequently in low SCC vs. high SCC herds (Hutton et al., 1990). Hueston et al. (1990) reported that milking last cows with clinical mastitis and those being treated for mastitis, an old management recommendation (Minett et al., 1933), was associated with lower SCC. Milking potentially infected cows last is an effective way to reduce IMI (Wilson et al., 1995). Teat spraying, a practice characterizing LOW herds, was generally considered to be equally effective to teat dipping for IMI control (Meaney, 1974; Pankey and Watts, 1983). Teat spraying is becoming commonplace (Hogan and Smith, 2001) for herdsmen particularly careful in animal hygiene. Teat dipping efficiency may depend on effects of temperature on germicidal activity of dipping solutions (Pankey, 1984). Regular cleansing of teat dip cups with a strong disinfectant is recommended to eliminate possible infection transfer from one cow to another (Van Damme, 1982). Because in our study the univariate statistical analysis indicated that the teat cups were more frequently cleaned in LOW herds, it could be hypothesized that teat dipping is not less effective per se, but through less teat-cup hygiene.

\section{CONCLUSIONS}

The ZMP indicated key practices, attitudes, and human qualities of herdsmen as part of control of SCS in French dairy farms applying the basic preventive measures. Four sets of characteristics including preventive rules and cultural practices must be carefully managed to prevent any significant increase in herd SCS in the short term. First, the herdsman must be specialized in dairy production and act with preciseness; then the lactating and dry cows must be housed in hygienic conditions. Calving conditions must be clean, and strict teat and udder hygiene conditions must be practiced. Finally, 2 strategies can be proposed to go toward the best SCS control in dairy herds. The first one should involve the selection of herdsmen on organizational aptitudes and on great rigor regarding hygiene. The second strategy would be to enroll the whole body of dairy farmers in a specific control preventive program. Such a program could consist of: (1) applying, in a rigorous way and during a 6-mo period, 3 practices that the farmer did not use before, from among those characterizing the LOW herds; (2) applying, at the end of the 6mo period, 3 other practices of his choice characterizing the LOW herds; (3) after 12 mo, making an assessment of the application level of the new performed practices; (4) engaging, over the second year, to set up all practices associated with the LOW herds. Nevertheless, the financially heavy characteristics (e.g., concerning the housing system) would only be adopted if the herdsman felt that they would induce a valuable improvement of the general farm functioning and guarantee a longterm economic profitability and better working conditions. All this process would contribute to set up a new attention and an increased spirit of rigor concerning udder hygiene and mastitis control in the herdsman.

\section{REFERENCES}

Agabriel, C., J. B. Coulon, C. Sibra, C. Journal, and A. Hauwuy. 1997. Facteurs de variation de la numération cellulaire du lait en exploitation. Ann. Zootech. (Paris) 46:13-19.

Albright, J. L., and W. R. Stricklin. 1989. Recent developments in the provision for cattle welfare. Pages 149-161 in New Techniques in Cattle Production. C. J. C. Phillips, ed. Butterworths, London, UK.

Barkema, H. W., Y. N. Schukken, T. J. G. M. Lam, M. L. Beiboer, G. Benedictus, and A. Brand. 1998a. Management practices associated with low, medium, and high somatic cell counts in bulk milk. J. Dairy Sci. 81:1917-1927.

Barkema, H. W., Y. H. Schukken, T. J. G. M. Lam, M. L. Beiboer, H. Wilmink, G. Benedictus, and A. Brand. 1998b. Incidence of clinical mastitis in dairy herds grouped in three categories by bulk milk SCC. J. Dairy Sci. 81:411-419.

Barkema, H. W., J. D. Van Der Ploeg, Y. N. Schukken, T. J. G. M. Lam, G. Benedictus, and A. Brand. 1999. Management style and its association with bulk milk somatic cell count and incidence rate of clinical mastitis. J. Dairy Sci. 82:1655-1663.

Barnouin, J. 1990. Components of the diet in the dry period as risk factors for milk fever in dairy herds in France. Prev. Vet. Med. 10:185-194.

Barnouin, J., and M. Chassagne. 2001. Predictive variables for the occurrence of early clinical mastitis in primiparous Holstein cows under field conditions in France. Can. Vet. J. 42:47-53.

Barnouin, J., M. Chassagne, S. Bord, E. Gay, P. Gasqui, N. Dorr, G. Sadot, and N. Blaszczik. 2002. Objectif Zéro Mammite, Lait 5 Etoiles (1999-2001) Résultats du Programme Collaboratif de Recherche. Ed. INRA EPI-A, Clermont-Ferrand, France.

Barnouin, J., J. C. Fayet, M. Jay, and B. Faye. 1986. Enquête écopathologique continue: Facteurs de risque des mammites de la Vache Laitière. II-Analyses complémentaires sur données individuelles et d'élevage. Can. Vet. J. 27:173-184.

Barnouin, J., N. Geromegnace, M. Chassagne, N. Dorr, and P. Sabatier. 1999. Facteurs structurels de variation des niveaux de comptage cellulaire du lait et de fréquence des mammites cliniques dans 560 élevages bovins répartis dans 21 départements français. Anim. Prod. 12:39-48.

Bartlett, P. C., G. Y. Miller, S. E. Lance, and L. E. Heider. 1992. Environmental and managerial determinants of somatic cell counts and clinical mastitis incidence in Ohio dairy herds. Prev. Vet. Med. 14:195-207.

Bendixen, P. H., B. Vilson, I. Ekesbo, and D. B. Astrand. 1988. Disease frequencies in dairy cows in Sweden. V. Mastitis. Prev. Vet. Med. 5:273-274.

Berry, E. A. 1998. Mastitis incidence in straw yards and cubicles. Vet. Rec. 142:517-518. 
Burvenich, C., V. van Merris, J. Mehrzad, A. Diez-Fraile, and L. Duchateau. 2003. Severity of E. coli mastitis is mainly determined by cow factors. Vet. Res. 34:521-564.

Coulon, J. B., P. Gasqui, J. Barnouin, A. Ollier, P. Pradel, and D. Pomies. 2002. Effect of mastitis and related-germ on milk yield and composition during naturally occurring udder infections in dairy cows. Anim. Res. 51:383-393.

Erskine, R. J., R. J. Eberhart, L. J. Hutchinson, and S. B. Spencer. 1987. Herd management and prevalence of mastitis in dairy herds with high and low somatic cell counts. JAVMA 190:1411-1416.

Faye, B., J. C. Fayet, M. Brochart, J. Barnouin, and P. Paccard. 1986. Enquête éco-pathologique continue. 4. Mise en évidence des associations pathologiques en élevage bovin laitier: données d'élevage. Ann. Rech. Vet. 17:257-264.

Fregonesi, J. A., and J. D. Leaver. 2001. Behaviour, performance and health indicators of welfare for dairy cows housed in strawyard or cubicle systems. Livest. Prod. Sci. 68:205-216.

Goff, J. 2003. Managing hypocalcemia and milk fever. Cattle Practice 11:75-79.

Goodger, W. J., S. Repp, and J. C. Galland. 1988. Toward developing an instrument for measuring milking management practices. Prev. Vet. Med. 6:109-126.

Hogan, J., and K. L. Smith. 2001. Mastitis fads and fashions. Special circular-Ohio Agricultural Research and Development Center. 182:71-74.

Hosmer, D. W., and S. Lemeshow. 1989. Applied Logistic Regression. John Wiley \& Sons, New York, NY.

Hueston, W. D., L. E. Heider, W. R. Harvey, and K. L. Smith. 1990. Determinants of high somatic cell count prevalence in dairy herds practicing teat dipping and dry cow therapy and with no evidence of Streptococcus agalactiae on repeated bulk tank milk examination. Prev. Vet. Med. 9:131-142.

Hutton, C. T., L. K. Fox, and D. D. Hancock. 1990. Mastitis control practices: Differences between herds with high and low milk somatic cell counts. J. Dairy Sci. 73:1135-1143.

Hutton, C. T., L. K. Fox, and D. D. Hancock. 1991. Risk factors associated with herd-group milk somatic cell count and prevalence of coagulase-positive staphylococcal intramammary infections. Prev. Vet. Med. 11:25-35.

Kelly, A. L., D. Tiernan, C. O'Sullivan, and P. Joyce. 2000. Correlation between bovine milk somatic cell count and polymorphonuclear leukocyte level for samples of bulk milk and milk from individual cows. J. Dairy Sci. 83:300-304.

Khaitsa, M. L., T. E. Wittum, K. L. Smith, J. L. Henderson, and K. H. Hoblet. 2000. Herd characteristics and management practices associated with bulk-tank somatic cell counts in herds in official dairy herd improvement association programs in Ohio. Am. J. Vet. Res. 61:1092-1098.

Mayo, N. S. 1895. Mastitis, inflammation of the mammary gland. Bulletin of the Experimental Station of the Kansas State Agricultural College, Manhattan 49:12-18.

Meaney, W. J. 1974. Post-milking teat disinfection: A comparison of dipping and spraying. Irish J. Agr. Res. 13:157-161.

Menzies, F. D., and D. P. Mackie. 2001. Bovine toxic mastitis: Risk factors and control measures. Ir. Vet. J. 54:30-37.

Minett, F. C., A. W. Stableforth, and S. J. Edwards. 1933. Studies on bovine mastitis. VIII. The control of chronic streptococcus mastitis. J. Comp. Pathol. 46:131-138.
Nonnecke, B. J., K. Kimura, J. P. Goff, and M. E. Kehrli. 2003. Effects of the mammary gland on functional capacities of blood mononuclear populations from periparturient cows. J. Dairy Sci. $86: 2359-2368$.

Noordhuizen, J. P. T. M., H. Woolrik, M. L. Vos, F. van Lipzig, and G. K. van Meurs. 1987. The potential use of cell count linear scores in veterinary herd health and production control on dairy farms: A preliminary report. Vet. Q. 9:60-66.

Pankey, J. W. 1984. Postmilking teat antisepsis. Vet. Clin. North Am. Large Anim. Pract. 6:335-348.

Pankey, J. W., and J. L. Watts. 1983. Evaluation of spray application of postmilking teat sanitizer. J. Dairy Sci. 66:355-358.

Peeler, E. J., M. J. Green, J. L. Fitzpatrick, K. L. Morgan, and L. E. Green. 2000. Risk factors associated with clinical mastitis in low somatic cell count British dairy herds. J. Dairy Sci. 83:2464-2472.

Rupp, R., D. Boichard, C. Bertrand, and S. Bazin. 2000. Overview of milk somatic cell counts in French dairy cattle breeds. INRA Prod. Anim. 13:257-267.

Sargeant, J. N., Y. N. Schukken, and K. E. Leslie. 2001. Ontario bulk milk somatic cell count reduction program: Progress and outlook. J. Dairy Sci. 81:1545-1554.

SAS User's Guide: Statistics, Version 8 Edition 1999. SAS Inst., Inc., Cary, NC.

Schukken, Y. H. 1990. Epidemiological studies on clinical mastitis in dairy herds with a low bulk milk somatic cell count. Ph.D. Diss., Univ. Utrecht, The Netherlands.

Schukken, Y. H., F. J. Grommers, D. Van de Geer, and A. Brand. 1989a. Incidence of clinical mastitis on farms with low SCC in bulk milk. Vet. Rec. 125:60-63.

Schukken, Y. H., F. J. Grommers, D. van de Geer, H. N. Erb, and A. Brand. 1990. Risk factors for clinical mastitis in herds with a low bulk milk somatic cell count. 1. Data and risk factors for all cases. J. Dairy Sci. 73:3463-3471.

Schukken, Y. H., D. van de Geer, F. J. Grommers, and A. Brand. 1989b. Assessing the repeatability of questionnaire data from dairy farms. Prev. Med. Vet. 7:31-38.

Seegers, H., C. Fourichon, and F. Beaudeau. 2003. Production effects related to mastitis and mastitis economics in dairy cattle herds. Vet. Res. 34:475-491.

Tarabla, H. D., and K. Dodd. 1990. Associations between farmer's personal characteristics, management practices and farm performance. Br. Vet. J. 146:157-164.

Tyler, J. W., B. J. Steevens, J. M. Holle, S. M. Croucher, and K. L. Anderson. 1998. Modification of postmilking standing time by altering feed availability. J. Dairy Res. 65:681-683.

Urech, E., Z. Puhan, and M. Schallibaum. 1999. Changes in milk protein fraction as affected by subclinical mastitis. J. Dairy Sci. 82:2402-2411.

Van Damme, D. M. 1982. Mastitis caused by contaminated teat dip and dipping cup. Vet. Med. Small Anim. Clin. 77:541-544.

Vavak, V. 1990. Climatic conditions of stanchionless housing and ethological manifestations of healthy and mastitic cows with regard to their occurrence and selection age. Acta Zoot. 46:199-212.

Wilson, D. J., R. N. Gonzalez, and P. M. Sears. 1995. Segregation or use of separate milking units for cows infected by Staphylococcus aureus: Effects on prevalence of infection and bulk tank somatic cell count. J. Dairy Sci. 78:2083-2085.

Zehner, M. M., R. J. Farnsworth, R. D. Appleman, K. Larntz, and J. A. Springer. 1986. Growth of environmental mastitis pathogens in various bedding materials. J. Dairy Sci. 69:1932-1941. 